\title{
MOBILIDADE ELÉTRICA
}

\section{Introdução}

No último século, a utilização de combustíveis fosseis permitiram uma acelerada industrialização intimamente associada a consumos crescentes de energia. Mas a sua utilização não é neutra do ponto de vista ambiental, pois liberta gases de efeito de estufa (GEE), que estão a alterar o equilíbrio da nossa atmosfera que existia no período préindustrial. Apoiado em estudos científicos cada vez mais credibilizados pela comunidade científica, o poder político está consciente das suas consequências climáticas, e por isso empenhado em mudar a matriz energética com vista a uma redução progressiva dos GEE.

\section{Problemas ambientais}

\subsection{Aquecimento da terra}

Como podemos observar na figura 2.1 (a), as temperaturas médias globais registadas na terra a na superfície do mar entre os anos 1850 e 2012 tiveram uma grande variação, sendo de salientar o crescimento progressivo e acentuado nas últimas três décadas. Neste período a subida máxima foi cerca de $1^{\circ} \mathrm{C}$, e se se considerar os valores médios por década o valor é inferior a 1ํㅡ. Há cada vez mais unanimidade científica das causas que estão a provocar esta subida acentuada da temperatura da terra. Como causa para esta subida são apontados os comportamentos humanas, ou seja, a queima de grandes quantidades de combustíveis fosseis, pós 1a revolução industrial, com a consequente libertação de GEE. Os especialistas do clima consideram que a subida da temperatura da terra não deverá ultrapassar os 1,5 a $2 \stackrel{\circ}{ }$, para não ser ultrapassado o limite de não retorno, pois caso seja ultrapassado entraríamos num período imprevisível de mudanças climáticas. É pois imperioso a redução dos GEE por todos os países de uma forma progressiva, sendo naturalmente mais importante nos mais poluidores.

(a)

Observed globally averaged combined land and ocean surface temperature anomaly $1850-2012$

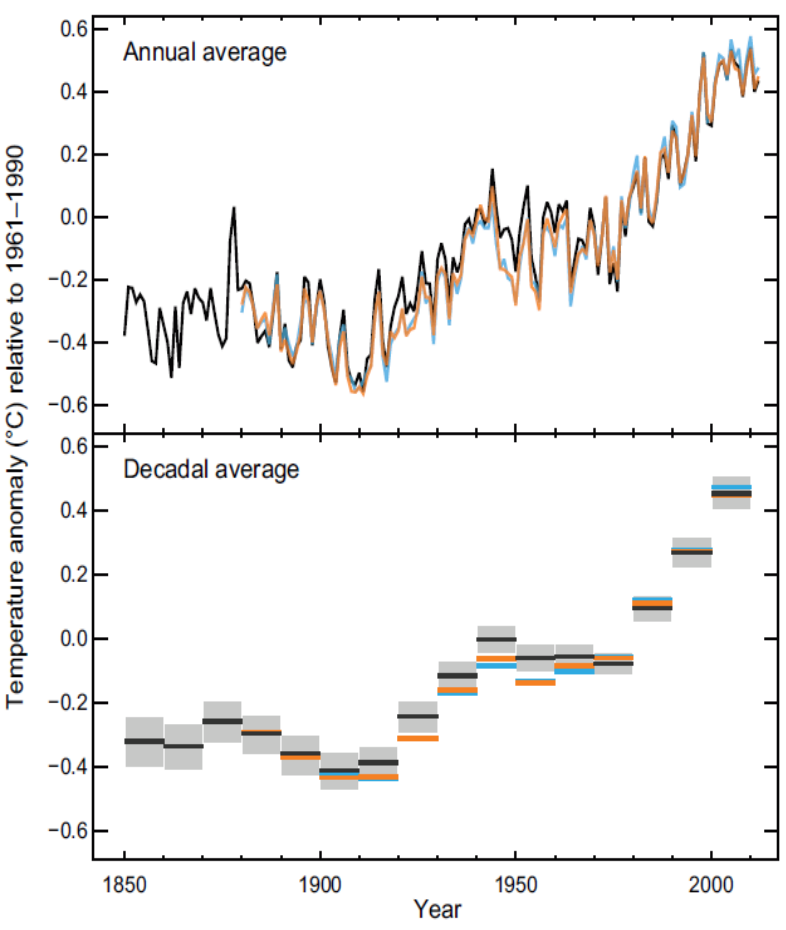

(b)

Observed change in surface temperature 1901-2012

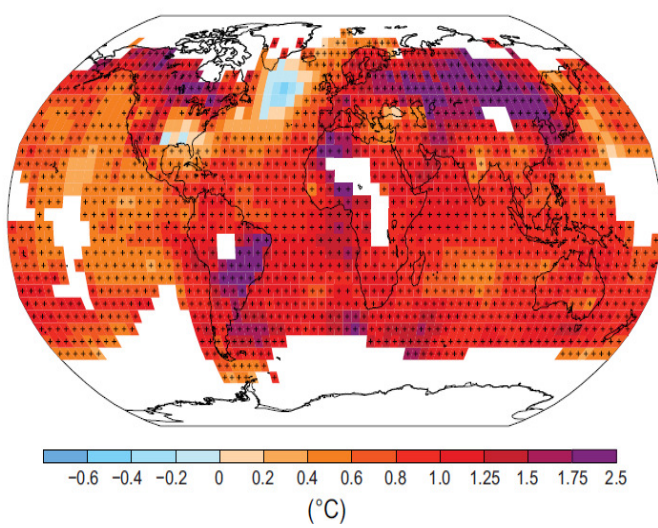

Figura 2.1. Variação das temperaturas médias globais na terra a na superfície do mar entre os anos de 1850 a 2012

(a) e variação das temperaturas à superfície da terra entre os anos de 1901 a 2012 (b) 
Outro aspeto também muito preocupante é a subida não uniforme da temperatura da terra. Nos registos efetuados entre os anos 1901 a 2012 das variações da temperatura na superfície, tanto na terra como no mar, ver figura 2.1 (b), apontam variações num intervalo de $-0,6$ ㅇ C a 2,5 ㅇ. As mudanças climáticas aumentaram o caracter aleatório do clima e descaracterizaram os períodos cíclicos das estações.

\subsection{Poluição nas cidades}

Atualmente, nas cidades vivem mais de $50 \%$ da população mundial, com um consumo de cerca de 60 a $80 \%$ da energia e que corresponde a $75 \%$ da produção dos GEE, devido à utilização de combustíveis fosseis nos transportes, climatização das habitações e produção de eletricidade. Em consequência a qualidade do ar atinge níveis preocupantes, pondo mesmo em risco a saúde humana e constituindo um grave e severo problema de saúde pública. Recentemente várias cidades da China atingiram valores record, entre elas Pequim onde durante vários dias a poluição foi extremamente elevada, cerca de 40 vezes o nível máximo.

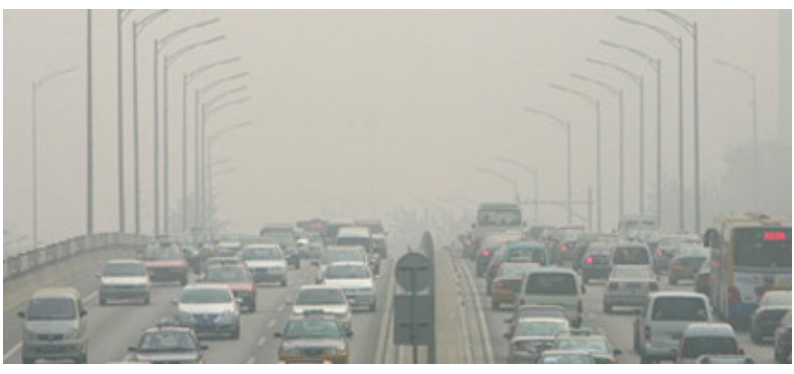

Figura 2.2. Poluição numa cidade devido ao tráfego rodoviário
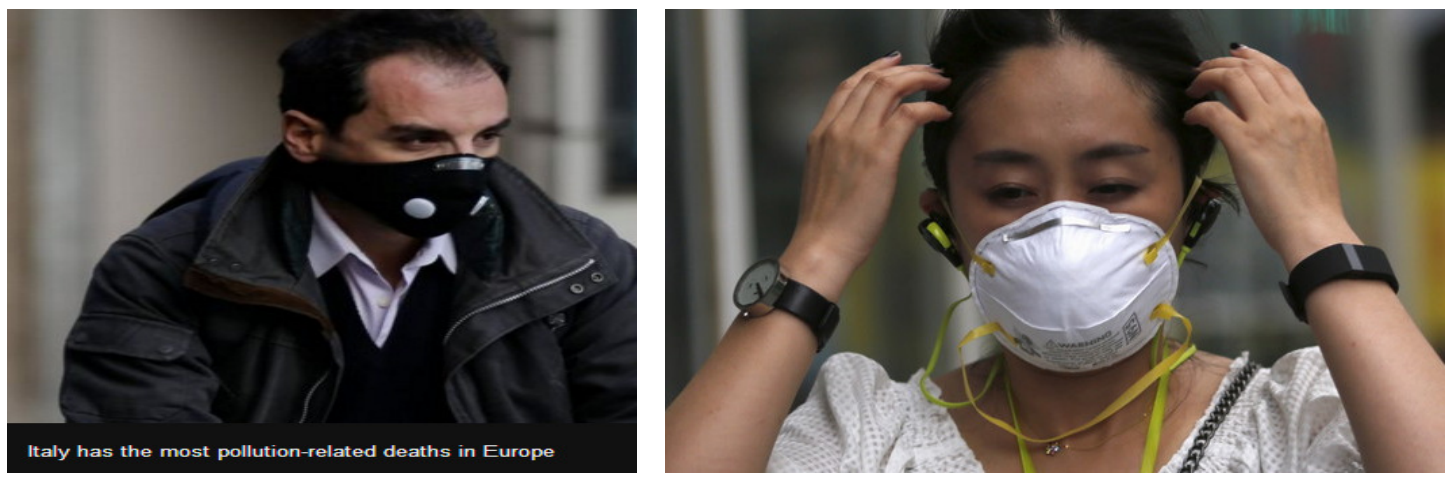

Figura 2.3. Utilização de máscaras para minimizar os efeitos da poluição das cidades 
A 1a fase, que entrou em vigor no dia 4 de julho de 2011, ver deliberação no 247/CM/2011, caracterizou-se pela restrição à circulação de veículos que não respeitassem as normas de emissão EURO 1 (veículos construídos antes de julho de 1992), das 8 às 20 horas nos dias úteis, período no qual se concentram as deslocações e emissões provenientes do tráfego rodoviário, no eixo da Av. da Liberdade/Baixa (limitado a norte pela Rua Alexandre Herculano e a sul pela Praça do Comércio), justificado pelas seguintes razões que se transcreve da mesma deliberação:

"8 - Nos últimos anos, a cidade de Lisboa tem apresentado concentrações partículas inaláveis (PM10) superiores aos valores limite estabelecidos pela legislação nacional e comunitária para proteção da saúde humana, sobretudo nas zonas de maior tráfego, situação que originou um processo de contencioso contra o Estado Português, tendo a Comissão Europeia intentado recentemente uma ação junto do Tribunal de Justiça Europeu por este incumprimento;

9 - O tráfego automóvel é, no momento presente, a principal causa da degradação da qualidade do ar na cidade de Lisboa, dado que é a principal origem de poluentes prejudiciais à saúde humana;".

Na 2 a fase que entrou em funcionamento a 1 de abril de 2012, ver deliberação no105/CM/2012, alargaram a área afeta à ZER que passou a compreender duas zonas (ver figura 2.4), e foram aumentadas as normas de emissão EURO ficando:

a) Zona 1: apenas podem circular veículos que respeitassem a norma de emissão EURO 2 (veículos construídos no ano de 1996 e posteriores);

b) Zona 2: apenas podem circular veículos que respeitassem a norma de emissão EURO 1 (veículos construídos no ano de 1992 e posteriores).

Na 3a fase da ZER de Lisboa, em vigor desde 15 de janeiro de 2015, foi aumentada a exigência em termos ambientais, passando a ser as seguintes:

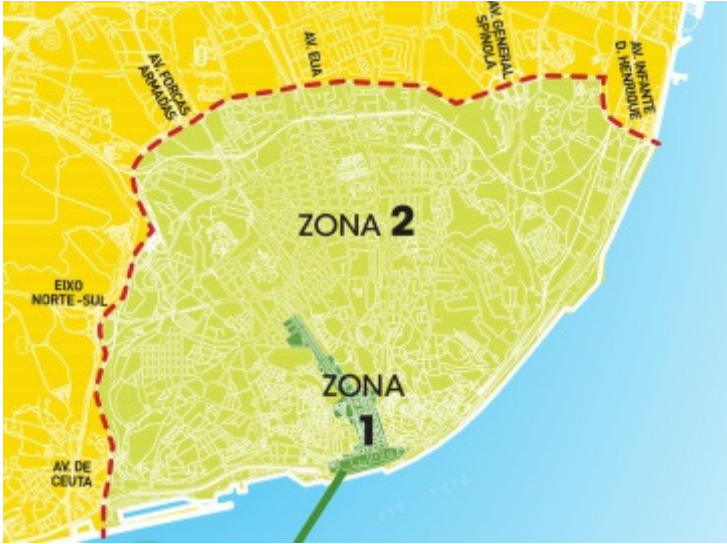

Figura 2.4. Áreas afetas à ZER na cidade de Lisboa

a) Zona 1 - apenas podem circular veículos que respeitem as normas de emissão EURO 3 (veículos ligeiros fabricados depois de janeiro de 2000 e pesados depois de outubro de 2000);

b) Zona 2 - apenas podem circula veículos que respeitem as normas de emissão EURO 2 (em geral, veículos ligeiros fabricados depois de janeiro de 1996 e pesados depois de outubro de 1996).

Sendo o problema da qualidade do ar transversal a todas as grandes cidades mundiais, o modelo utilizado em Lisboa também já está a ser implementado noutras capitais como Madrid ou Paris, que já criaram planos para progressivamente restringir numa primeira fase a circulação dos carros mais poluentes, e numa segunda fase proibir a circulação dos veículos poluidores, permitindo só a circulação de veículos zero emissão (ZEV).

Numa posição recente do governo Alemão, a partir de 2030 todos os carros novos registados na Alemanha terão que ser ZEV, para que possam cumprir as suas metas de redução de poluição. O parlamento holandês recentemente aprovou por maioria uma moção para que só haja vendas de ZEV a partir de 2025, meta que a Noruega também está empenhada em cumprir. Em Paris no ano passado, durante a última Conferência do Clima, foi constituída a Aliança Internacional dos Veículos Zero Emissão com o objetivo de a partir de 2050 todos os veículos comercializados serem ZEV. 


\section{Veículos zero emissão}

Os ZEV são cruciais para criarem uma solução alternativa aos veículos com motores de combustão interna $(\mathrm{MCl})$, cuja evolução em termos de emissões tem evoluído mas que será impossível anular completamente, por limitações tecnológicas. São sinais dessa limitação tecnológica os recentes escândalos pela manipulação por várias marcas das emissões poluentes. A estratégia dos construtores automóveis tem sido muito diversa em relação à diminuição das emissões poluentes. Atingido um limite de evolução do $\mathrm{MCl}$ à volta das $100 \mathrm{~g}$ por $100 \mathrm{~km}$, uma maior redução já é possível com a recuperação da energia cinética nas travagens regenerativas, evoluindo para os híbridos (ver figura 3.1). Noutra estratégia adotada por outros construtores permitiu o desenvolvimento de modelos com emissão zero, que se dividem em: veículo elétrico com fuell cell (FCVE) e o veículo elétrico (VE), como mostra a figura 3.1.

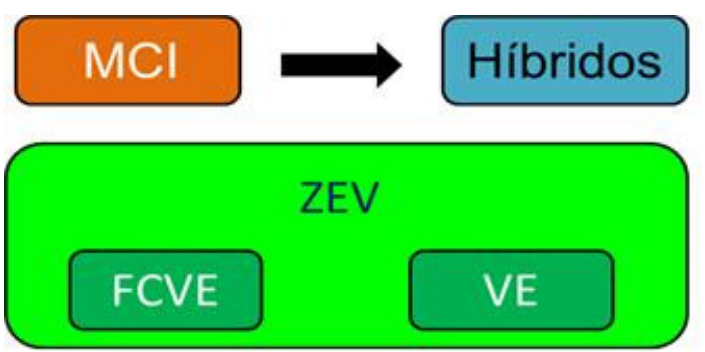

Figura 3.1. Evolução das tecnologias dos automóveis atuais

\subsection{Veiculo elétrico com fuel cell}

O FCVE é um automóvel com acionamento elétrico que utiliza as Fuel Cell para converter o hidrogénio em energia elétrica com a finalidade de carregar as baterias. Atualmente na Europa já estão a ser comercializados pela Hyndai o ix35 Fuell Cell e pela Toyota o Mirai.

\section{TOYOTA MIRAI}

O Toyota Mirai (figura 3.2) tem um motor elétrico com 151 CV e uma bateria elétrica de níquel de hidretos metálicos (NiMH). O hidrogénio é armazenado num deposito com a capacidade de $5 \mathrm{~kg}$ que permite uma autonomia de $500 \mathrm{~km}$.
O tempo de reabastecimento é só de 5 minutos, criando uma situação equiparada aos $\mathrm{MCl}$.

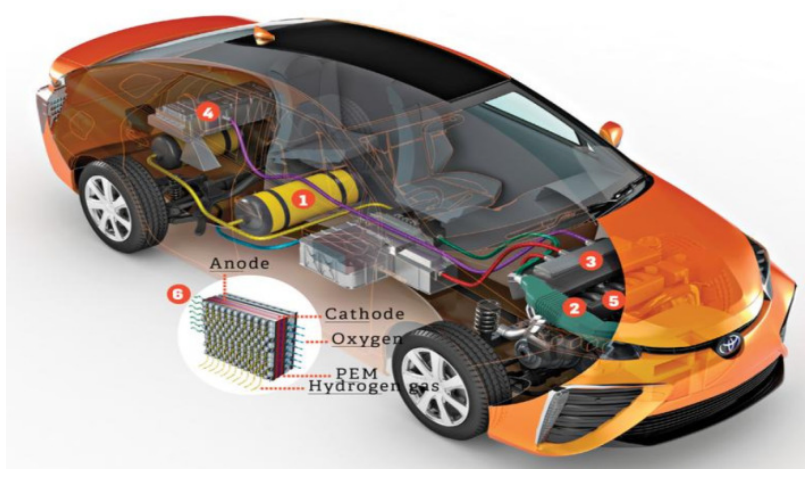

Figura 3.2. Toyota Mirai

Uma das vantagens dos FCVE face aos VE á a sua autonomia já atingir os 600 km (ix35 Fuell Cell da Hyndai). Outra vantagem é a elevada fiabilidade da fuel cell, pois um carro da GM já superou os $400.000 \mathrm{~km}$ numa fase de testes e poder utilizar o hidrogénio produzido a partir energia electrica gerada de excedentes de energias renováveis, situação existente atualmente em alguns países no norte da Europa.

Uma das desvantagens dos FCVE face aos VE é o seu preço, pois nesta primeira fase em que não são produzidos em grandes series, são mais caros. O preço atual do hidrogénio (comercializado a cerca de 10 euros por quilograma na Alemanha e Dinamarca) é sem dúvida a maior desvantagem, ficam comparaveis aos $\mathrm{MCl}$, mas com um custo por quilometro mais elevado que os VE.

Atualmente as vendas dos FCVE face aos VE são reduzidas, mas são expressivas no norte da Europa, concretamente na Alemanha, Dinamarca e Inglaterra, onde a rede de abastecimento tem crescido e permitindo o seu abastecimento. A Dinamarca será o primeiro país do mundo a ter uma rede nacional de abastecimento de hidrogénio, permitindo a sua circulação em todo o país e ligações à Alemanha, ver figura 3.3 (esquerda). Como se pode ver na figura 3.3 (direita), na Dinamarca o hidrogéneo é mais um combustível disponibilizado num posto de abastecimento da Shell, ao lado do GPL (LPG na sigla inglesa). 

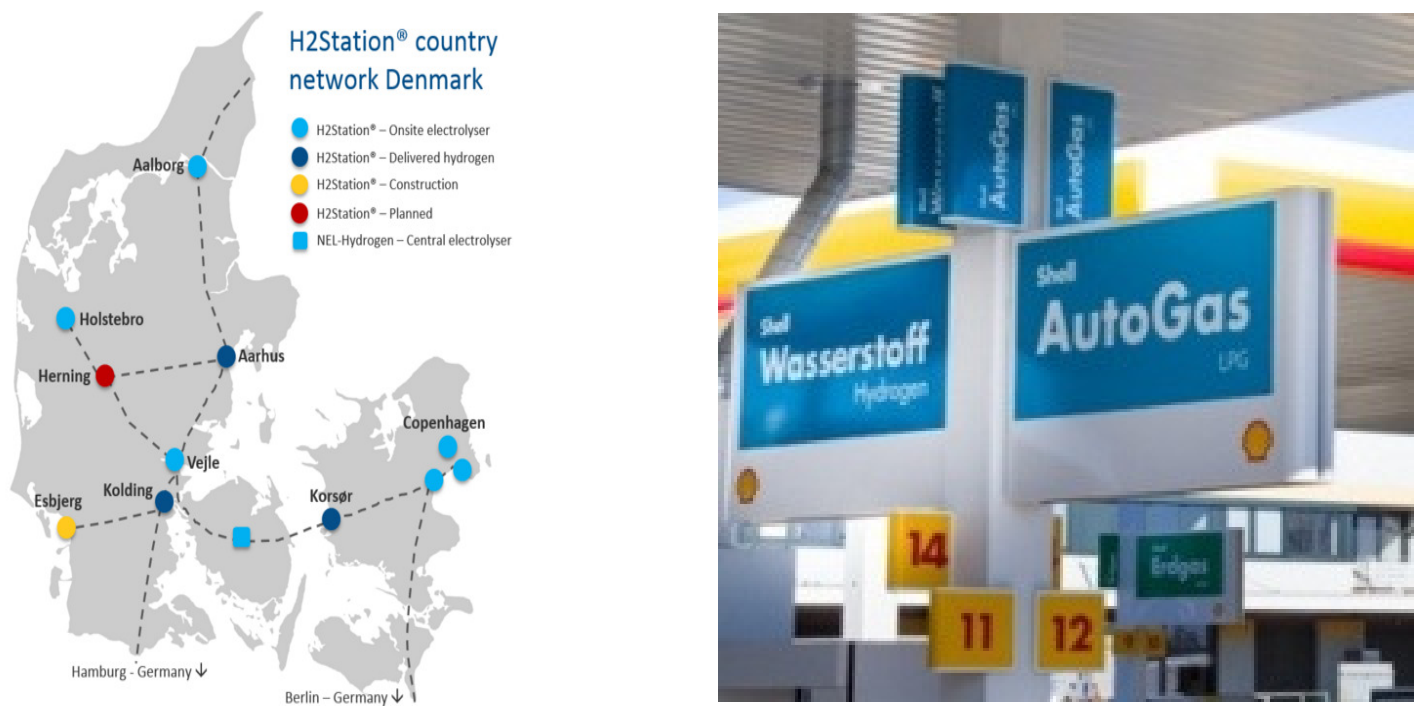

Figura 3.3. Rede de abastecimento de hidrogénio e posto de abastecimento de hidrogénio na Dinamarca

\subsection{Veículos elétricos}

O automóvel elétrico é um veículo com acionamento elétrico alimentado a partir de baterias, cuja autonomia está dependente da capacidade de armazenamento da mesma bateria.

Em 2015, em todo o mundo, foram vendidos 565.000 VE com um crescimento de $80 \%$ face ao ano anterior, mas correspondendo a $0,63 \%$ das vendas mundiais, pois no mesmo ano foram vendidas 89,7 milhões de carros novos.

Como se pode ver na figura 3.4 , a China foi o país com maiores vendas em 2015, ultrapassando as 200.000 unidades e praticamente triplicando face ao ano anterior, mesmo assim corresponde a uma cota das vendas totais muito reduzida. Por outro lado, na Noruega a cota de vendas de VE face aos veículos convencionais já ultrapassou os $20 \%$ [IEA].

Um dos aspetos que tem sido apontado como inibidor da maior penetração dos VE é o custo das baterias, mas como se pode ver na ver figura 3.5 , o custo das baterias tem diminuído substancialmente, enquanto que a sua densidade energética tem aumentando. As metas definidas por dois construtores (GM e Tesla) para os próximos anos, mostram a evolução que se prespetiva a curto prazo, e sendo no sentido de uma acentuada melhoria destes dois parâmetros.

\section{EV sales and market share in a selection of countries and regions, 2015}

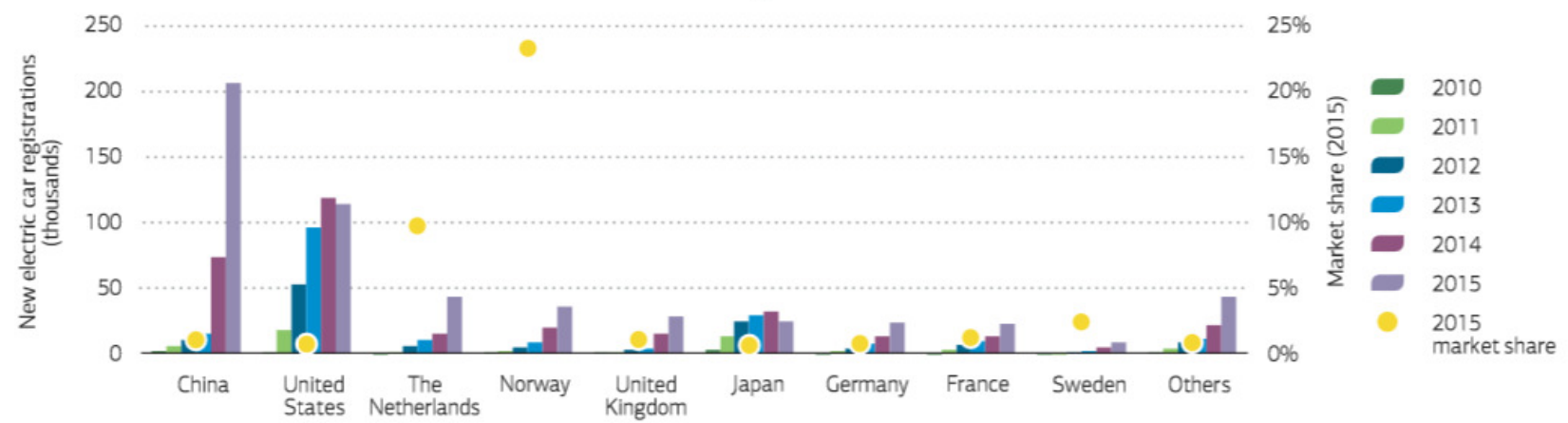

Figura 3.4. Evolução das vendas de VE nos últimos cinco anos [IEA] 
Battery cost (PHEV)

2020 Tesla Battery cost target (BEV)

2022 Battery cost target (PHEV)

2022 GM Battery cost target (BEV)

Energy density (PHEV)

2022 Energy density target (PHEV)

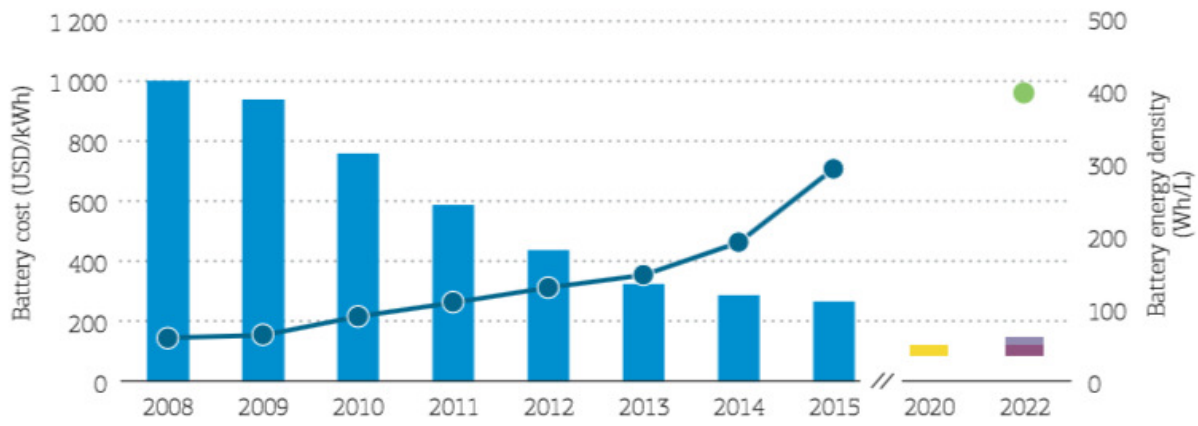

Figura 3.5. Evolução do custo e da densidade energética das baterias [IEA]
Um estudo publicado em Novembro de 2015 pela Union of Concerned Scientists [www.ucsusa.org/] compara as emissões nos seus "ciclos de vida" de veículos elétrico com bateria (BEV) com os veículos a gasolina semelhantes. Os dois BEV estudados são os dois modelos mais vendidos nos Estados Unidos atualmente: o Nissan LEAF (midsize) e o Tesla Model S (full-size). Tem em conta as emissões para a produção de eletricidade para alimentar os dois BEV e avalia as emissões em todo o ciclo de vida, tendo em conta:

- As matérias-primas para fabrico dos carros;

- O seu fabrico;

- Consumo de combustível na sua vida útil;

- A sua eliminação ou reciclagem.

Os valores encontrados neste estudo são claramente esclarecedores, pois há uma redução de $51 \%$ no carro de gama média e 53\% no carro de gama alta, ver figura 3.6, para os valores globais de emissão.

Uma das vantagens dos VE face aos FCVE é o seu preço, pois comparativamente são mais baratos. Ao utilizarem diretamente a energia elétrica são mais eficientes do ponto de vista energético e torna o seu custo por quilómetro mais reduzido.

As desvantagens dos VE face aos FCVE irão na próxima década desaparecer, já que a autonomia ultrapassará os 500 km. Está prevista uma forte redução do custo das baterias com o aumento de escala a sua produção, e um aumento acentuado da sua fiabilidade e durabilidade.
FIGURE 7. Life Cycle Global Warming Emissions from the Manufacturing and Operation of Gasoline and Battery-Electric Vehicles

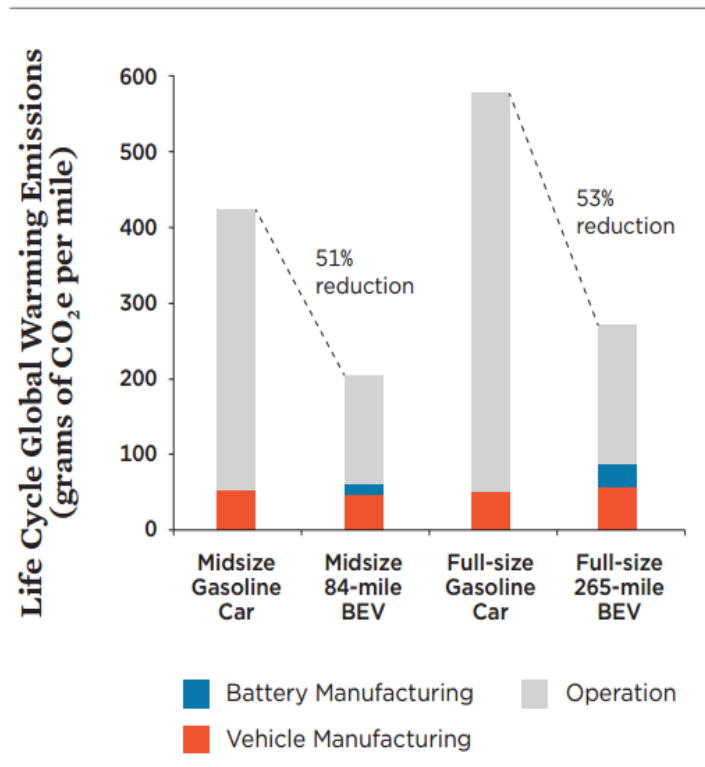

Figura 3.6. Comparação das emissões globais entre VE e carros a gasolina [www.ucsusa.org/]

\section{Mobilidade elétrica}

Os primeiros VE foram construídos na década de 30 do século XIX (ver figura 4.1) e só passado 50 anos é que é descoberto o ciclo termodinâmico OTTO que permitiu a construção dos $\mathrm{MCl}$. Em 1900, 28\% dos carros nos USA eram elétricos. Com a era do petróleo barato, os carros com $\mathrm{MCl}$ dominaram completamente o mercado automóvel. No início do século XXI, os problemas ambientais, as sucessivas crises do petróleo e a evolução das baterias provocaram o renascer do seu interesse. 


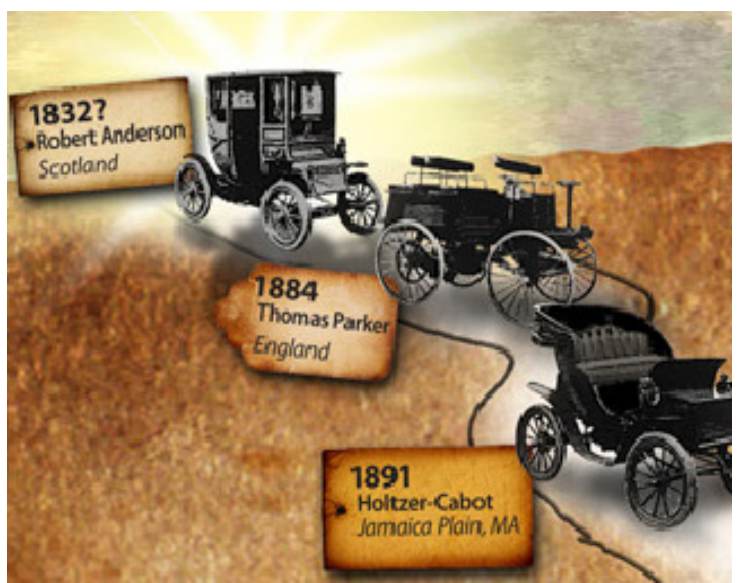

Figura 4.1. Os primeiros VE

Atualmente estão disponíveis os VE, de gama média, considerados de primeira geração, com uma bateria até 30 kWh e autonomia até $200 \mathrm{~km}$, ver figura 4.2. A partir de 2017 será comercializado a 2 a geração em que a bateria e a autonomia é duplicada em relação à primeira geração. Prevê-se que em 2020 será comercializado a 3ạ geração com valores triplos dos atuais.

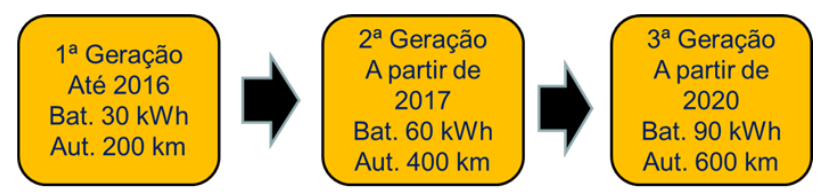

Figura 4.2. As várias gerações de VE de gama média

\subsection{Situação atual}

A situação atual dos VE é caracterizada pelo domínio de dois modelos de duas marcas: o Nissan Leaf, na gama média, e o Modelo S da Tesla, na gama alta (berlinas de luxo). Mas o seu êxito está a provocar mudanças na estratégia dos fabricantes de referência, perspetivando-se na próxima década o lançamento de muitos modelos elétricos, para também responderem à necessidade de redução de poluição que muitos governos querem cumprir para atingirem as metas que politicamente estão comprometidos.

É exemplo dessa mudança a recente divulgação de o grupo VW do objetivo de lançar 30 modelos elétricos até 2025 e querer liderar o mercado dos VE, prevendo o fabrico de 2 a 3 milhões destes modelos em 2025. Após esta divulgação, o grupo FIAT e o grupo Land Rover Jaguar alteraram também a sua estratégia, no sentido de incrementarem o desenvolvimento de VE. De seguida são analisados os dois VE que dominaram o mercado em 2015.

\section{- $\quad$ NISSAN LEAF}

O Nissan Leaf (figura 4.3) tem um motor elétrico síncrono de ímanes permanentes, com 109 CV (280 NM) e a sua velocidade máxima é limitada a $145 \mathrm{~km} / \mathrm{h}$. A sua bateria de iões de lítio está colocado na plataforma (piso) e inicialmente tinha a capacidade de $24 \mathrm{kWh}$, mas a partir de janeiro de 2016 também já está disponível com bateria de 30 kWh. O fabricante aponta melhorias da autonomia muito acima do aumento da capacidade da bateria por evolução química da mesma.

A autonomia medido no ciclo NEDC (europeu) é de $199 \mathrm{~km}$ (24 kWh) e $250 \mathrm{~km}$ (30 kWh). Com o ciclo EPA (americano) a autonomia baixa para $135 \mathrm{~km}$ (24 kWh) e 172 km (30 kWh), devido a este ciclo exigir no seu teste $55 \%$ dos quilómetros percorridos serem em cidade e $45 \%$ em autoestrada. $O$ consumo médio é de $15 \mathrm{kWh} / 100 \mathrm{~km}$ (ciclo NEDC) e subindo para $18,6 \mathrm{kWh} / 100 \mathrm{~km}$ (ciclo EPA).

O tempo de carga irá depender da potência disponível. Nas nossas garagens com uma tomada de $3,3 \mathrm{~kW}(16 \mathrm{~A})$ em cerca de 8 horas ( $24 \mathrm{kWh} / 3,3 \mathrm{~kW}$ ) e com uma tomada com 6,6 kW em cerca de 4 horas ( 24 kWh/6,6 kW). Com carga rápida de 50 kW DC, 80\% da carga demorará cerca de 30 minutos.

Após 5 anos de vendas, as baterias dos Leaf vendidos na Europa registam uma taxa de fiabilidade de $99,99 \%$, pois o fabricante divulgou que foram substituídas unicamente 2 baterias em 35.000 unidades vendidas. Estes primeiros dados sobre a fiabilidade e durabilidade da bateria do Leaf são muito importantes, não se confirmando o receio inicial sobre as baterias, que se apontava a necessidade de as substituir ao fim de 3 a 5 anos. 

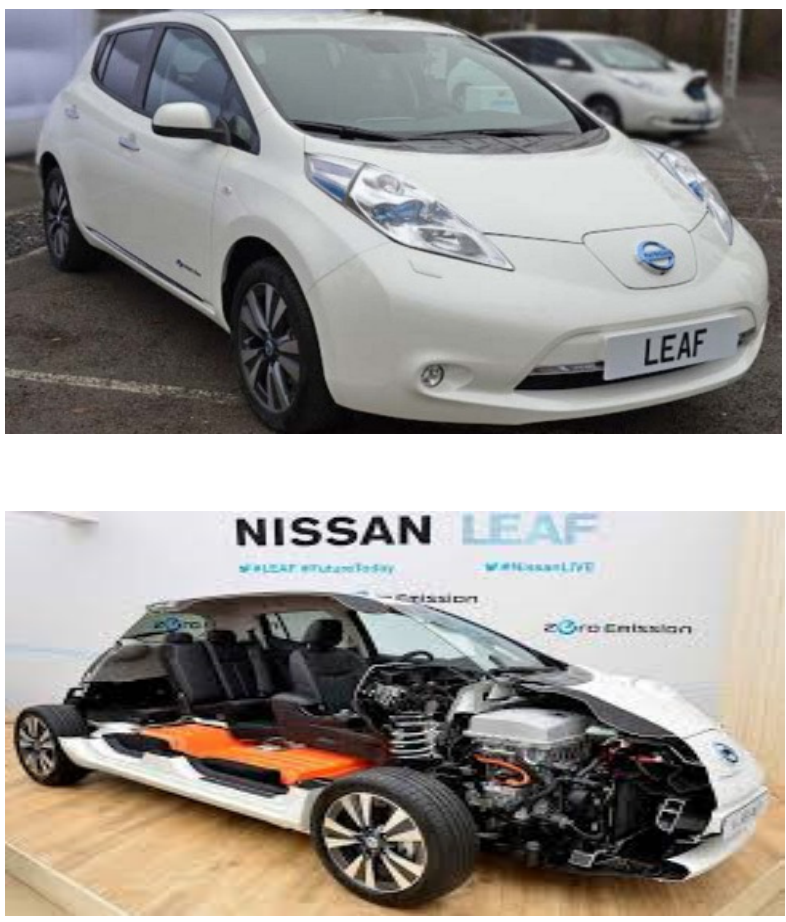

Figura 4.3. Nissan Leaf

Sendo os VE à partida considerados carros citadinos, foi recentemente divulgado um caso que contraria esta afirmação. Um Nissan Leaf com 5 anos adquirido nos USA, o seu proprietário (Steve Marsh) anda $200 \mathrm{~km}$ diariamente. Com a mesma bateria ( $24 \mathrm{kWh}$ ) já percorreu $241.000 \mathrm{~km}$ e a autonomia atual é $52 \%$ da inicial (70 km reais), ou seja já perdeu 5 das 12 barras. A perda de autonomia tem a ver com o número de cargas que são realizadas, mas o futuro aumento da capacidade da bateria irá minimizar este problema, pois com uma carga irá aumentar a autonomia e por isso necessitando de menos cargas.

Outro Nissan Leaf com 3 anos vendido no Porto, o seu proprietário (António Flores) anda $50 \mathrm{~km}$ diariamente. Com a mesma bateria (24 kWh) já percorreu $28.631 \mathrm{~km}$ e a autonomia atual é igual à inicial, ou seja, ainda não perdeu nenhuma das 12 barras, ver figura 4.4 (direita). Na mesma figura, também se pode ver que com a bateria a $100 \%$ a autonomia atinge $162 \mathrm{~km}$, um valor entre os valores dos dois ciclos referidos anteriormente, pois este calculo é efetuado com base do histórico dos últimos consumos.
Como se pode ver na parte esquerda da figura 4.3, o consumo médio acumulado é de cerca de $15 \mathrm{kWh} / 100 \mathrm{~km}$, ou seja o custo até ao momento foi de 1,5 euros/100 km, se se considerar carga noturna no período de vazio com dupla tarifa (0,1 euro/kWh).
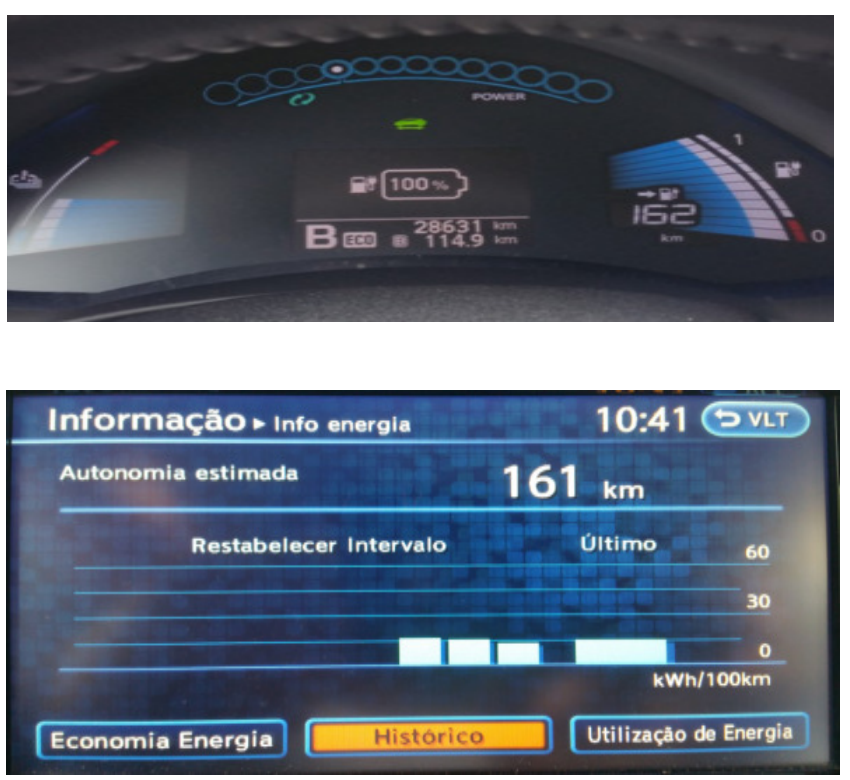

Figura 4.3. Situação de um Nissan Leaf com 3 anos

As frotas como as dos táxis, por percorrerem muitos quilómetros diariamente, são importantes para aferir a fiabilidade e durabilidade dos carros. Por outro lado, os VE são os carros ideais para serem usados como táxis, dado que circulam maioritariamente nas zonas urbanas, muitas horas por dia, e são em termos ambientais neutros.

Por estas razões, é importante a recente divulgação pela Nissan referente às vendas de Leaf e e-NV200 para frotas de táxis (figura 4.4). As vendas atingiram as 550 unidades em 17 países europeus e 44 cidades.

Os táxis europeus diariamente percorrem em média $240 \mathrm{~km}$ tendo um custo de manutenção inferior em 40 \% face aos carros diesel.

Um táxi na Estónia já percorreu 214.000 km, mas não é referido se manteve a mesma bateria. 


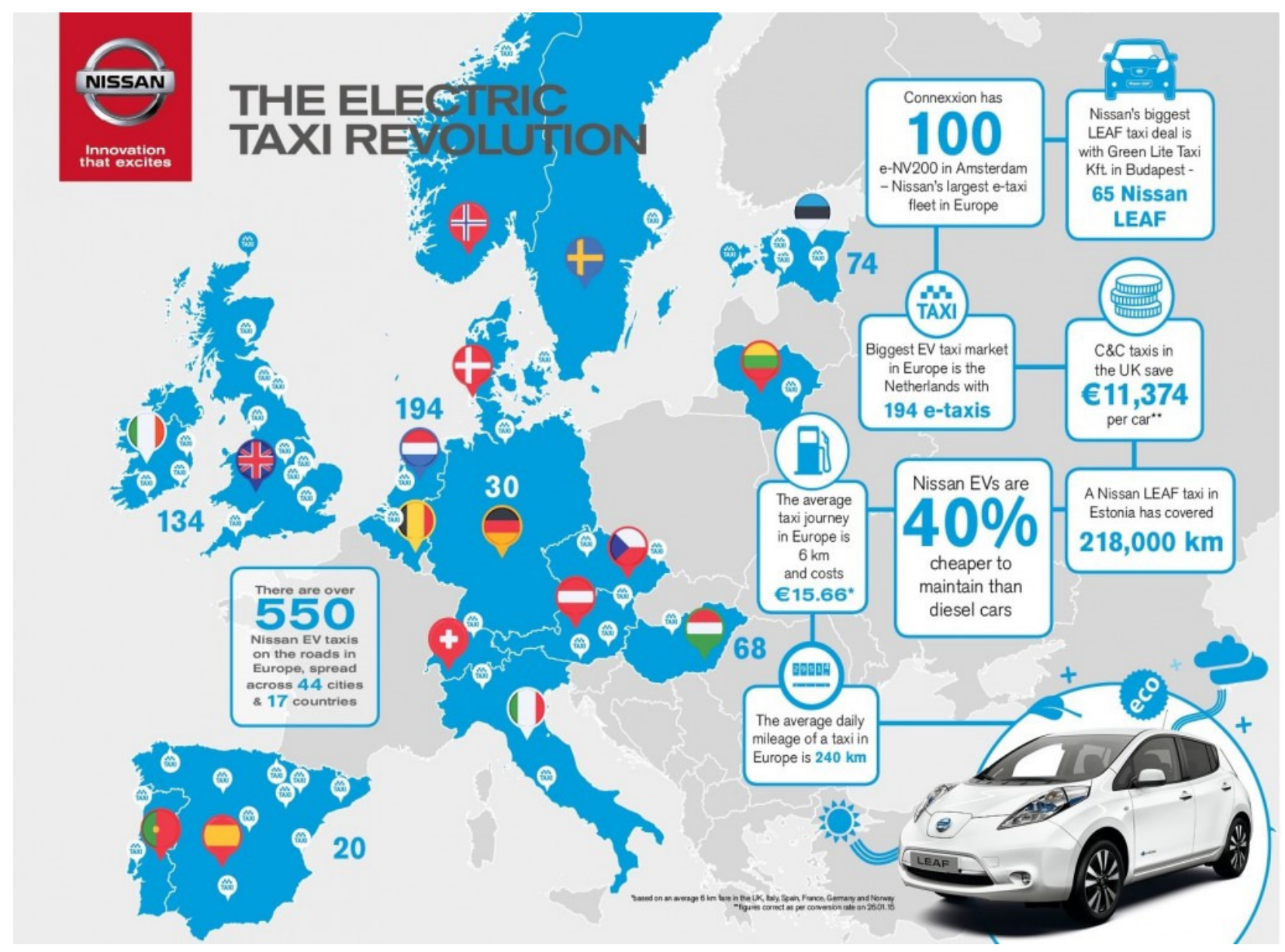

Figura 4.4. Vendas da Nissan para frotas de táxis

\section{- TESLA MODELO S}

A Tesla Motors é uma empresa americana fundada em 2003, com a finalidade de desenvolver e comercializar carros elétricos. O Modelo S é o segundo modelo lançado pela Tesla em 2012 e pertence ao segmento da gama alta (figura 4.5 esquerda).

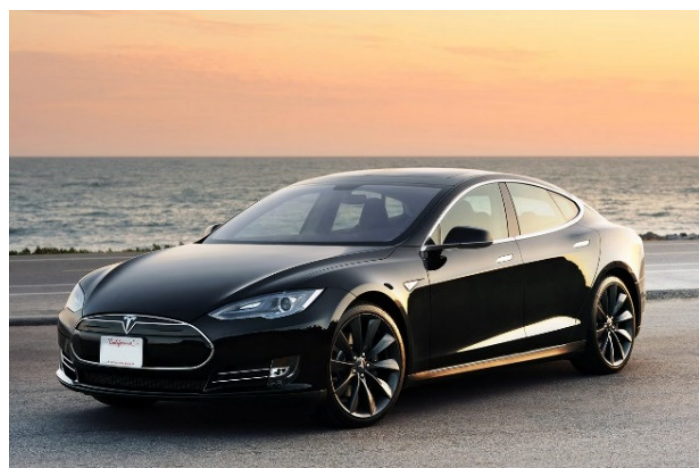

A sua bateria está colocada na plataforma, ver figura 4.5 esquerda, e dado o seu peso (544 kg para a versão de 85 kWh) baixa o centro de gravidade e aumenta a estabilidade do carro. Utiliza 1 motor de indução trifásico (334 CV/439 NM a $428 \mathrm{CV} / 600 \mathrm{NM}$ ) ou 2 motores para a tração às quatro rodas (totalizando $700 \mathrm{CV} / 931 \mathrm{NM}$ ), consoante a versão, figura 4.5 direita.

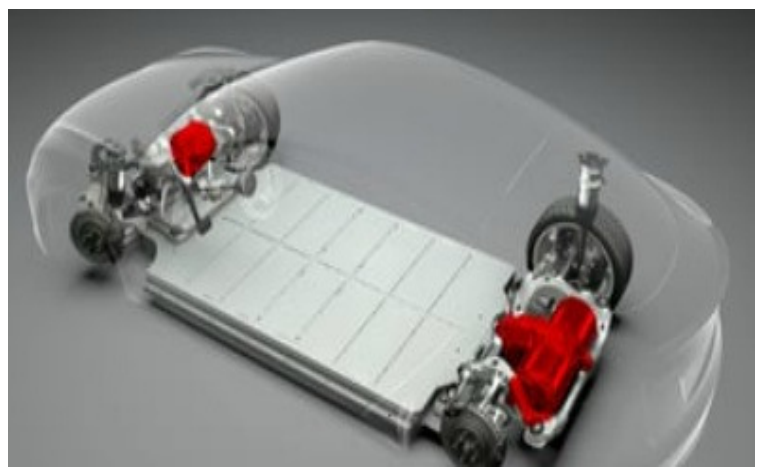

Figura 4.5. O Tesla Model S 
Na versão mais performance percorre os 0 a $100 \mathrm{~km}$ em 3 segundos. A bateria tem evoluído com ganhos crescentes de capacidade, e neste momento são disponibilizadas baterias com 70, 85 e 90 kWh e em breve haverá uma subida para $100 \mathrm{kWh}$.

A autonomia, no ciclo EPA, está entre os $386 \mathrm{~km}$ (70 kWh) até aos $460 \mathrm{~km}$ (90 kWh). A tesla prevê na próxima década o aumento da autonomia para $1.000 \mathrm{~km}$. A velocidade máxima é de $225 \mathrm{~km} / \mathrm{h}$ (70 kWh) e $250 \mathrm{~km}$ (85 kWh). O consumo médio (ciclo EPA), está entre 20,49 kWh/100 km (70 kWh) e os $22,36 \mathrm{kWh} / 100 \mathrm{~km}$ (85 kWh). Vem com um carregador interno de $10 \mathrm{~kW}$ ou por opção de 20 kW, e em 30 minutos ganha uma autonomia de $480 \mathrm{~km}$ nos supercarregadores de $120 \mathrm{~kW}$ que a Tesla disponibiliza.

Em 2015 e segundo a Forbes, na Europa a berlina de luxo mais vendida foi o Tesla S (15.787 unidades) seguida pelo Mercedes S (14.990), com 4000 unidades vendidas na Noruega. Nos USA no ano de 2015, também foi a berlina de luxo mais vendida, ver figura 4.6, sendo o único modelo que em 2015 aumentou as vendas face ao ano anterior. Sendo este segmento muito importante e valioso em termos financeiros, a liderança da Tesla no mercado europeu e americano, é já uma ameaça às marcas tradicionais, provocando já uma mudança de estratégia de algumas marcas face aos VE. É também de salientar a apetência dos consumidores para esta nova solução tecnológica ambientalmente neutra. De salientar também que no ano de 2015 foi o VE mais vendido (42.730) seguido pelo Nissan Leaf (42.270).

\section{- Fiabilidade}

Num estudo realizado pela revista Plug in América [http://www.pluginamerica.org], a partir de dados reais dos proprietários dos Teslas $\mathrm{S}$, chegaram à seguinte conclusão: a bateria de $85 \mathrm{kWh}$ após $160.000 \mathrm{~km}$ percorridos apresenta uma redução inferior a $10 \%$ de autonomia. Esta redução é verificada na linha de tendência no gráfico da figura 4.7.

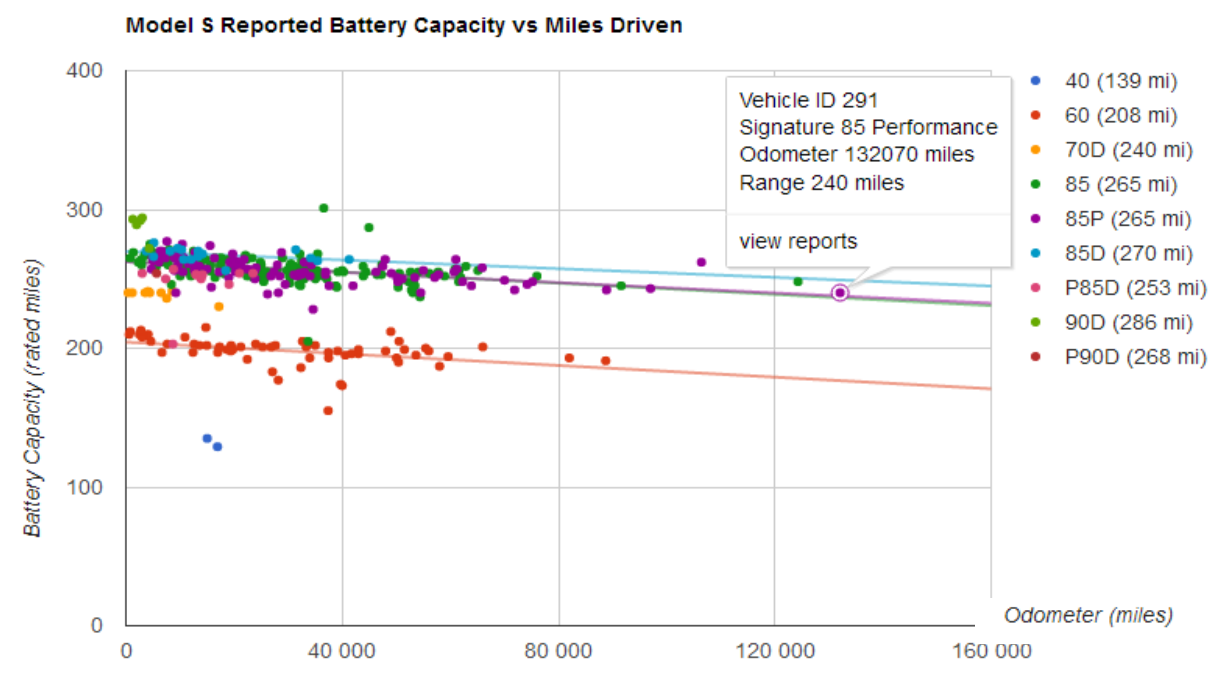

Figura 4.7. Redução da autonomia do Tesla Model S

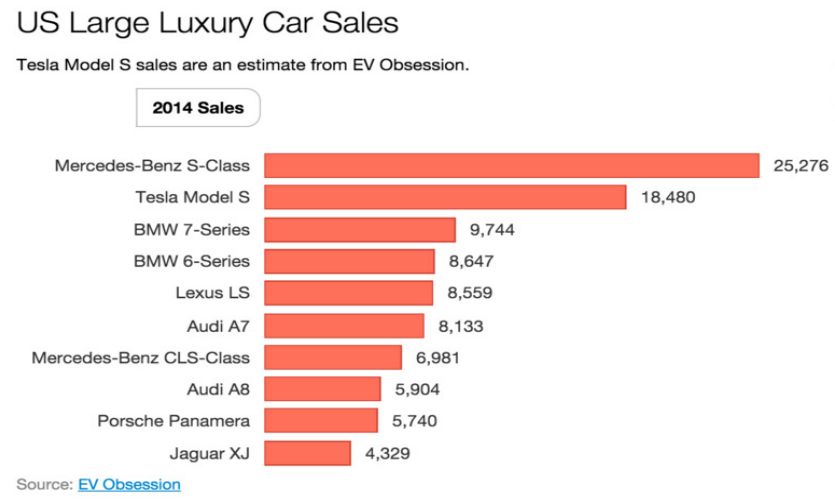

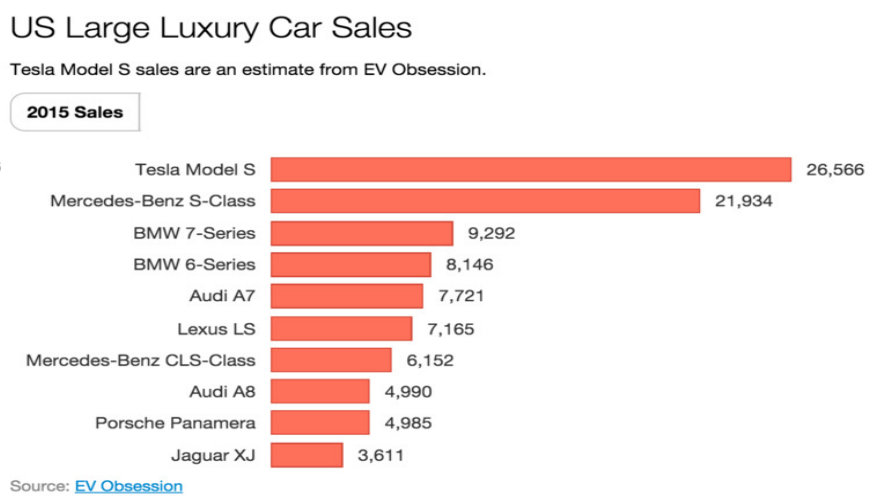

Figura 4.6. Vendas do Tesla Model S em 2014 e 2015 nos USA 
No mesmo estudo são reportados os dados da manutenção/reparação em relação ao ano de fabrico e apresentados na figura 4.8. Estes dados não cobrem todas as unidades vendidas pela Tesla, ver vendas no lado direita do figura 4.8, o que relativiza os mesmos dados. Mas é de salientar a redução da taxa de avarias nos modelos mais recentes face às unidades fabricadas nos primeiros 3 anos. As avarias reportadas localizam-se nas unidades de tração, baterias e carregadores.

\section{- Situação real}

O taxista francês Stéphane Arputzo (fig. 4.9 esquerda) que trabalha na zona de Marselha comprou um Tesla Model S 85, no passado mês de Dezembro. Aponta como motivos para a sua compra:

- $\quad$ ter condução autónoma;

- $\quad$ ser muito confortável por ter suspensão pneumática;

- Muito económico, espera poupar 11.000 por ano, dado que por dia anda $500 \mathrm{~km}$ e cerca de $12.000 \mathrm{~km}$ por mês;
- Vai de Marselha a Paris (750 km de ida e volta) realizando cargas nos pontos de carga rápida da Tesla (fig. 4.9 direita).

\section{- Autocarros}

Outro segmento que a mobilidade elétrica irá contribuir para a redução de poluição em geral e em especial nas cidades é no sector de transporte rodoviário de passageiros. Atualmente os autocarros utilizam $\mathrm{MCl}$ a diesel ou gás natural.

O fabricante chinês BYD, neste momento lidera o mercado mundial de autocarros elétricos com uma produção em 2015 de 10.000 unidades. São dotados de baterias de 345 kWh (lítio de fosfato de ferro), que lhes permite uma autonomia de $310 \mathrm{~km}$, suficiente para os trajetos a realizar num dia. Recentemente forneceu autocarros para a cidade de Londres, com dois andares, dando uma garantia de 12 anos para a sua bateria (figura 4.10 esquerda). O fabricante espanhol IRIZAR já lançou o seu autocarro elétrico em Espanha, com bateria de sódio-níquel de 376 kWh e um motor elétrico com $313 \mathrm{CV}$ (figura 4.10 direita).

\begin{tabular}{|c|c|c|c|c|c|}
\hline Year & Vehicles & $\begin{array}{l}\text { Median Odo } \\
\text { Miles }\end{array}$ & $\begin{array}{l}\text { Drive Unit } \\
\text { Swap \% }\end{array}$ & $\begin{array}{l}\text { Battery } \\
\text { Swap \% }\end{array}$ & $\begin{array}{l}\text { Charger } \\
\text { Swap \% }\end{array}$ \\
\hline 2012 & 106 & 29,284 & 37.7 & 16.0 & 9.4 \\
\hline 2013 & 255 & 23,450 & 29.4 & 5.9 & 4.3 \\
\hline 2014 & 70 & 17,500 & 20.0 & 1.4 & 5.7 \\
\hline 2015 & 52 & 9,012 & 3.8 & 1.9 & 0.0 \\
\hline \multirow[t]{2}{*}{2016} & 9 & 1,114 & 0.0 & 0.0 & 0.0 \\
\hline & 492 & & & & \\
\hline
\end{tabular}

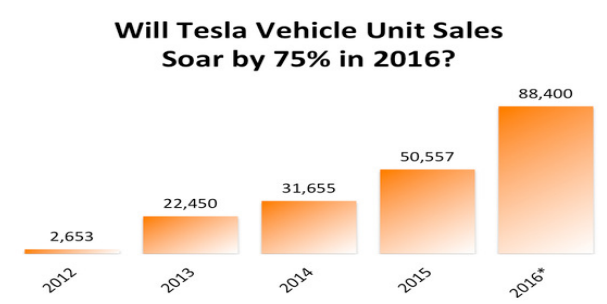

Figura 4.8. Dados da manutenção/reparação e correspondentes vendas em relação ao ano de fabrico do Tesla Model S
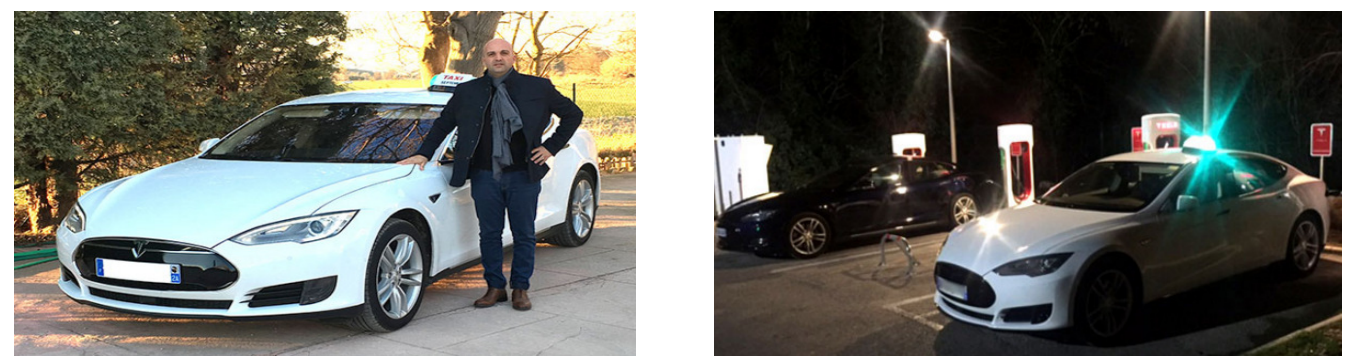

Figura 4.9. Redução da autonomia do Tesla Model S 

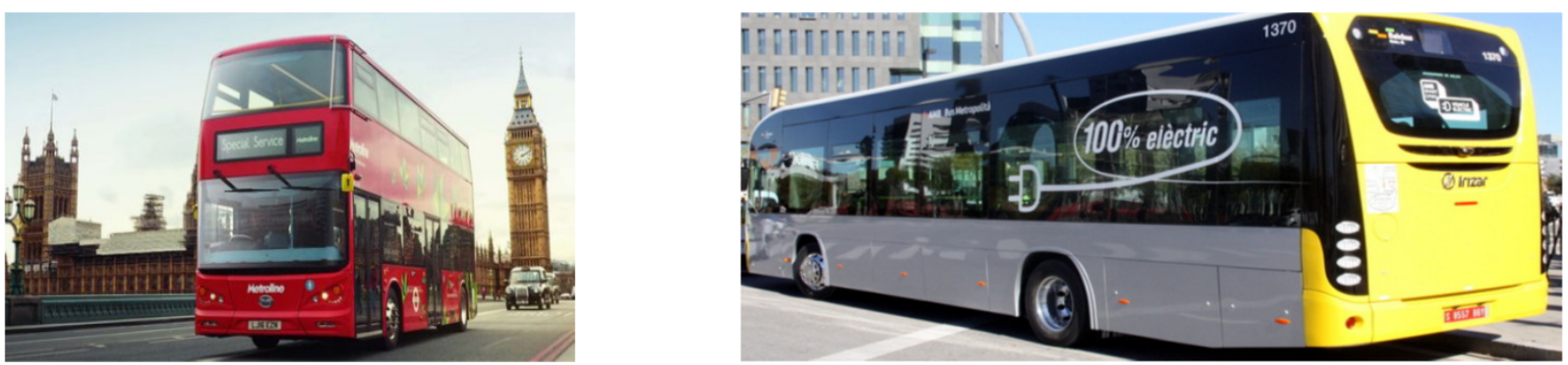

Figura 4.10. Autocarro elétrico BYD (esquerda) e Irizar (direita)

O fabricante português Salvador Caetano, recentemente apresentou um novo autocarro para transporte urbano $100 \%$ elétrico e silencioso - o e.City Gold (figura 4.11), totalmente desenvolvido em Portugal. Segundo o fabricante, o investimento inicial é superior face aos tradicionais a gasóleo mas recuperável em 6 anos.

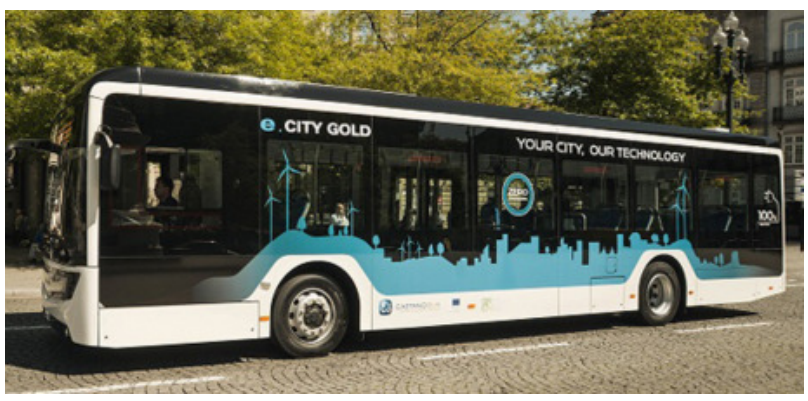

Figura 4.11. Autocarro elétrico o e.City Gold, da Salvador Caetano

\section{- Camiões}

O transporte rodoviário de cargas é outro segmento que a mobilidade elétrica permitirá contribuir para a redução de poluição.

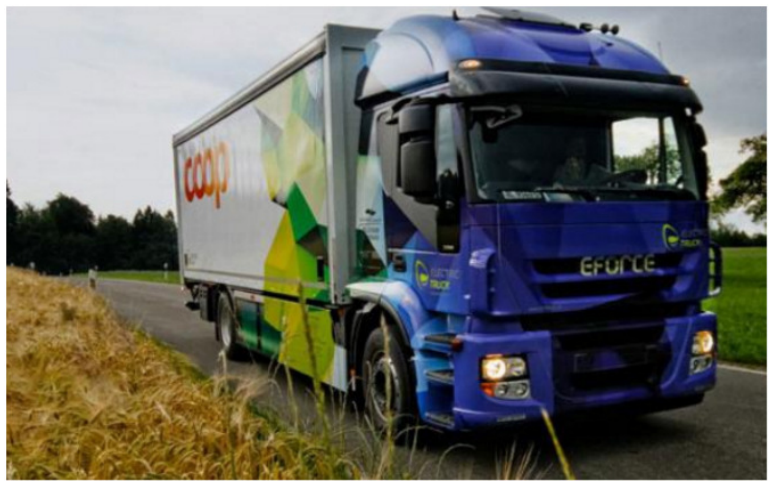

A IVECO desenvolveu o camião elétrico de 18 toneladas EFORCE (figura 4.12 esquerda), com baterias de 240 kWh (lítio de fosfato de ferro), com uma autonomia de $200 \mathrm{~km}$ (autoestrada) e $300 \mathrm{~km}$ (cidade). O tempo de carga da bateria é de 6 horas com um carregador de $44 \mathrm{~kW}$. Os consumos apontados são de 60 a $90 \mathrm{kWh} / 100 \mathrm{~km}$, dependente do tipo de trajeto. Um camião equivalente a gasóleo tem um consumo de 31 litros.

O grupo Daimler desenvolveu em Portugal, no Tramagal, a FUSO ELECTRIC CANTER (figura 4.12 direita) numa versão experimental para testes. Os 8 camiões de 3 toneladas fabricados tiveram um cofinanciamento do Governo Português através do IAPMEI. Dotado de um motor elétrico com $150 \mathrm{CV} / 650 \mathrm{NM}$ e baterias de 48,4 kWh (iões de lítio) que permitem uma autonomia de $100 \mathrm{~km}$. Os testes foram realizados em frotas de várias Camaras Municipais, CTT e REN. Após o período de testes, os resultados apontam para uma poupança nos custos operativos de $65 \%$, ou seja 1.000 euros por cada $10.000 \mathrm{~km}$ percorridos.

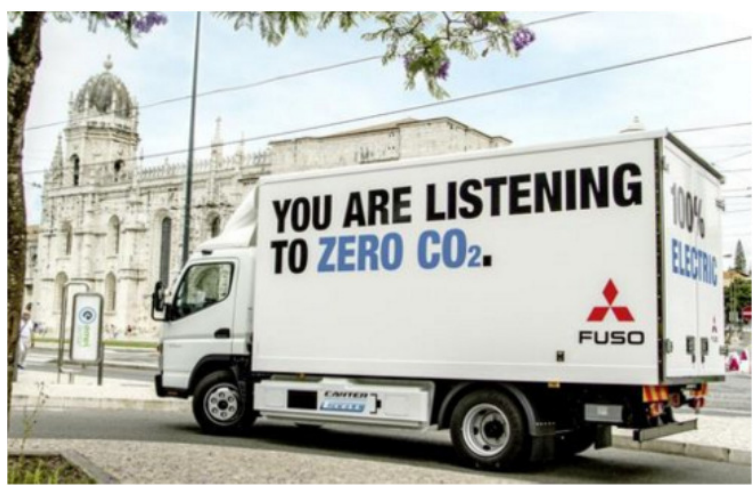

Figura 4.12. Camião elétrico IVECO E-FORCE e o FUSO ELECTRIC CANTER 


\section{ARTIGO TÉcNICO}

\section{- Bicicletas e motas}

As bicicletas e motas permitem uma grande mobilidade nas cidades e por isso são imprescindíveis para a mobilidade elétrica.

Várias marcas consagradas lançaram no mercado bicicletas elétricas, como por exemplo o grupo Daimler que já comercializa a bicicleta elétrica Smart (figura 4.13), com uma autonomia de $100 \mathrm{~km}$ e travagem regenerativa.

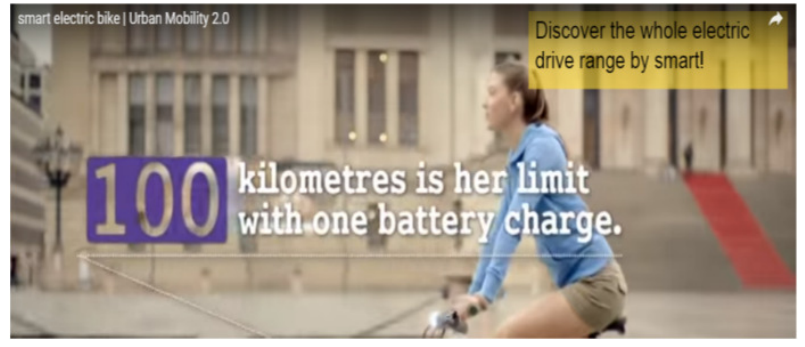

Figura 4.13. Bicicleta elétrica Smart

Os fabricantes tradicionais de motas estão atrasados em fornecer soluções elétricas, mas como se pode ver na figura 4.14 já existem modelos elétricos no mercado.

\subsection{Situação futura (2016 a 2018)}

Os VE estão a atravessar uma fase de grande dinâmica e evolução que irá permitir torná-los numa opção cada vez mais interessante para os consumidores. $\mathrm{O}$ que se perspetiva a curto prazo irá aumentar a autonomia, com as atualizações das baterias de 1 a geração:

- A VW irá atualizar o seu e-golf (figura 4.15 esquerda) em 2016. O motor elétrico irá evoluir de 116 CV para $164 \mathrm{CV}$ e a bateria de 24,2 para $35,8 \mathrm{kWh}$, passando a autonomia para $300 \mathrm{~km}$ (ciclo NEDS) ou 174 km (ciclo EPA);

- A BMW irá atualizar o seu i3 (figura 4.15 centro) em 2016. A bateria irá evoluir de 22 para 33 kWh, só por evolução tecnológica mantendo o seu peso e volume ocupado, aumentando a autonomia para $183 \mathrm{~km}$ (ciclo EPA);

- A Hyundai irá lançar o seu primeiro VE (figura 4.15 direita) em 2016 na Europa. O loniq, terá um motor elétrico com $120 \mathrm{CV}$ e bateria de $28 \mathrm{kWh}$. A autonomia anunciada é de $169 \mathrm{~km}$ (ciclo EPA).

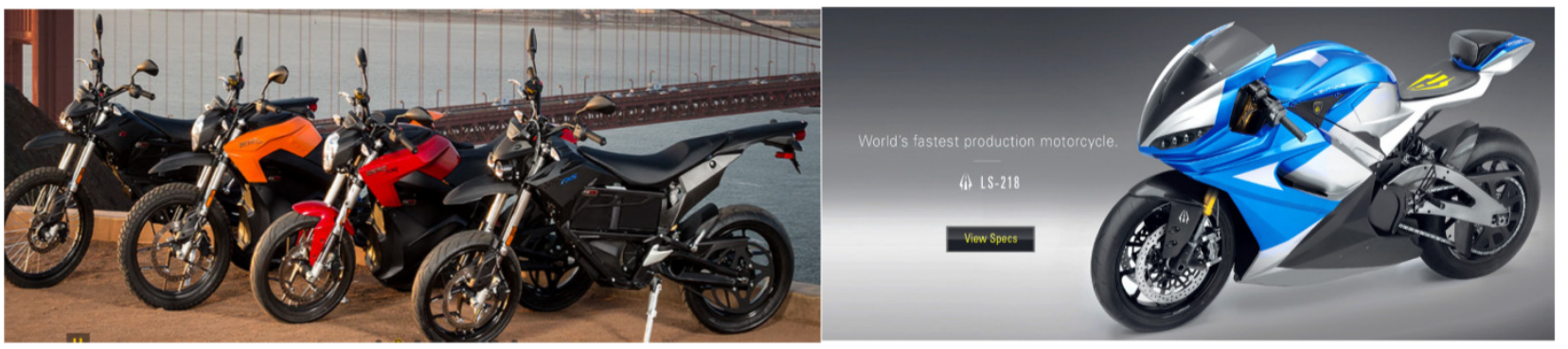

Figura 4.14. As motas elétricas ZERO (www.zeromotorcycles.com) e a LIGHTNING (http://lightningmotorcycle.com/)
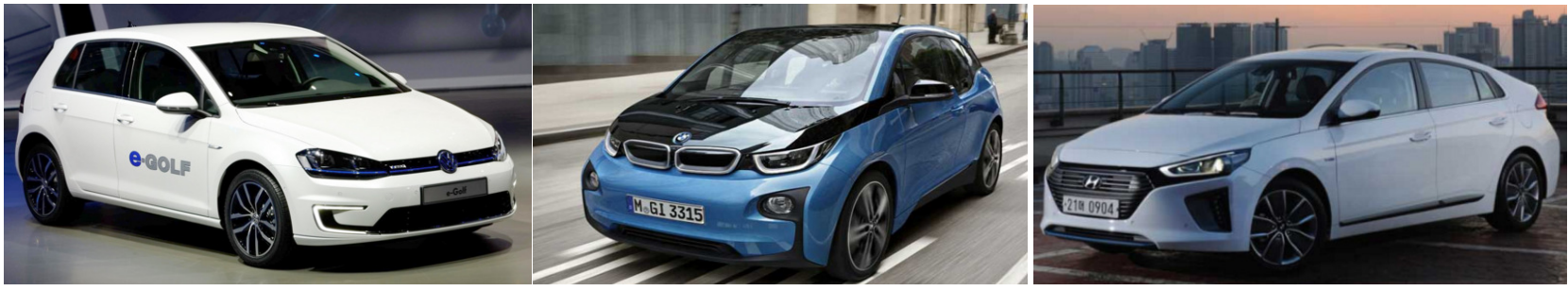

Figura 4.15. VW e-Golf, BMW i3 e o novo Hyunday loniq 
O primeiro VE de segunda geração, do segmento médio, será lançado pela Opel em 2017. O Ampera-e (figura 4.16 esquerda), virá com motor elétrico com 200 CV e uma aceleração de 0 a $100 \mathrm{~km}$ num tempo inferior a $7 \mathrm{~s}$. Dotado da primeira bateria de $60 \mathrm{kWh}$ do segmento em que se insere, terá uma autonomia de $320 \mathrm{~km}$ em fase de homologação pelo ciclo EPA.

A Tesla apresentou o seu primeiro VE do segmento médio no passado dia 31 de Março. O Modelo 3 (figura 4.16 centro) terá um motor acima dos 200 CV que irá permitir uma aceleração de 0 aos $100 \mathrm{~km}$ num tempo inferior a $6 \mathrm{~s}$. Dotado também com uma bateria de $60 \mathrm{kWh}$, terá uma autonomia anunciada de $345 \mathrm{~km}$ ainda não homologada pela EPA. A Tesla esperava, numa previsão mais otimista, que ao fim do primeiro mês tivesse 135.00 reservas provenientes de todo o mundo, mas as reservas subiram até às 373.000 unidades, o que cria uma situação extremamente complexa para um fabricante que em 2015 produziu só 55.557 VE.

A Nissan irá lançar em 2018 o novo Leaf (figura 4.16 direita) com bateria de $60 \mathrm{kWh}$ e autonomia de $547 \mathrm{~km}$ (ciclo NEDS). Mas irá manter a bateria de $30 \mathrm{kWh}$ numa versão mais barata, para clientes que a sua menor autonomia não será crítica.

\subsection{Carregamento de bateria}

Nos VE toda a energia está armazenada na sua bateria, necessitando periodicamente de ser carregada a partir de um ponto de carga alimentado por energia elétrica. O tempo de carga é um dos fatores mais críticos apontados a este tipo de veículos.
As baterias atuais, além das cargas lentas com um tempo de carga dependente da potência disponível do ponto de carga, também já admitem cargas rápidas com tempo de carga típico de 30 minutos. Na situação mais simples e económica, o carregamento poderá ser efetuado a partir de uma tomada doméstica, nas nossas casas.

\section{Carregamento doméstico}

Para ser possível realizar o carregamento doméstico, a instalação elétrica da habitação tem que disponibilizar no mínimo a potência de $3,3 \mathrm{~kW}$. Caso o contrato de fornecimento de energia elétrica for de dupla tarifa, o carregamento lento noturno do VE é o mais económico, por utilizar a tarifa mais baixa. O número de horas necessárias para carregar a bateria irá depender da capacidade da bateria e do seu nível de descarga, como já analisado anteriormente.

Nas garagens coletivas dos prédios as tomadas normalmente são de serviços comuns, levantando por isso vários tipos de problemas: como realizar o controlo do consumo para posterior pagamento e a potência disponível irá limitar o número de VE, no mesmo prédio, a carregar em simultâneo. As redes elétricas foram projetadas tendo em conta fatores de simultaneidade inferiores a 1 , pois na prática verifica-se que a probabilidade de em simultâneo os consumidores ligarem as suas cargas elétricas é baixa, diminuindo consoante aumento o número de consumidores considerados. Com a perspetiva da crescente penetração dos VE para as próximas décadas, a probabilidade de em simultâneo os consumidores colocarem os seus VE em carga lenta, aumenta, e em consequência poderá levar à

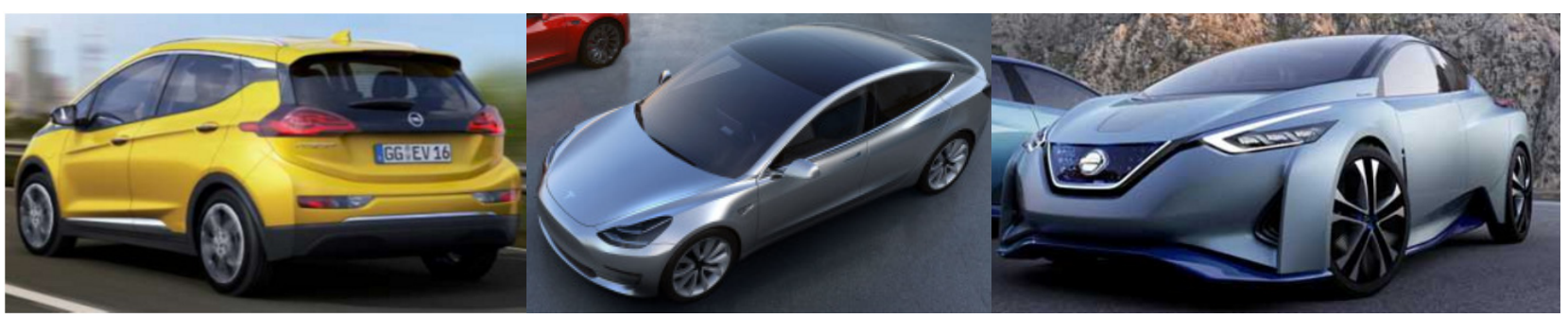

Figura 4.16. Opel Ampera-e, Nissan Leaf versão 2018 e Tesla Modelo 3 
saturação das redes elétricas. Está saturação poderá ser ao nível de alimentação BT da nossa rua ou prédio, no próprio PT ou mesmo nas redes MT. Uma possível solução passará pela gestão inteligente das redes elétricas, ajustando a hora do carregamento do VE de cada consumidor, de acordo com a disponibilidade da rede, tendo em conta o seu perfil de necessidade diária de carga.

\section{- Rede pública de carregamento}

Portugal tem uma Rede Nacional de Mobilidade Elétrica (MOBI.E) com 442 pontos de carga, sendo na maioria pontos de carga lentos $(3,7 \mathrm{~kW})$ e em número reduzido de pontos de carga rápida (50 kW ou superior). Com as baterias atuais (30 kWh), um ponto de carga lento colocado na via pública, no limite, fica ocupado cerca de 8 horas (30 kWh/3,7 kW) só por um VE, limitando a possibilidade de outras usufruírem de um bem que é público. Com a prevista duplicação da capacidade das baterias dos modelos do segmento médio (60 kWh), este problema irá se agravar, tornando estes pontos de carga ainda mais desadequados. Uma possível solução é a evolução para pontos de carga rápida adquados às novas exigências que as $2^{a}$ e e 3 a geração de VE irão exigir.

A Tesla sempre considerou que este seria um problema crítico para a penetração dos seus VE no mercado automóvel e por isso está a desenvolver uma rede mundial de postos de supercarregamento com $120 \mathrm{~kW}$ (ver figura 4.17), que permitem em 30 minutos carregar $60 \mathrm{kWh}$. Mas, aconselha os seus clientes a realizarem normalmente o carregamento lento nas suas casas, caso percorram curtas distâncias diariamente, e a utilizarem os seus supercarregadores nas suas deslocações mais longas.

Em Portugal está prevista a abertura de três postos de supercarregamento: Porto, Lisboa e Algarve (figura 4.18 direita), sendo o número suficiente para percorrer o nosso país, dado o seu nível de autonomia atual. Em Espanha já estão em funcionamento os postos de Madrid, valência, Granada e Murcia. O posto de Murcia utiliza as infraestruturas de um centro comercial e localiza-se junto a duas autoestradas (figura 4.18 direita). A Tesla está agora empenhada de instalar além dos seus supercarregadores, também lentos, em diversos pontos onde as suas vendas justifiquem e onde já existam infraestruturas elétricas: hotéis, centros comerciais e mesmo postos de abastecimento convencionais. Para ter acesso à sua rede mundial de supercarregadores é necessário o pagamento inicial de 2000 dólares, sendo depois os carregamentos grátis.

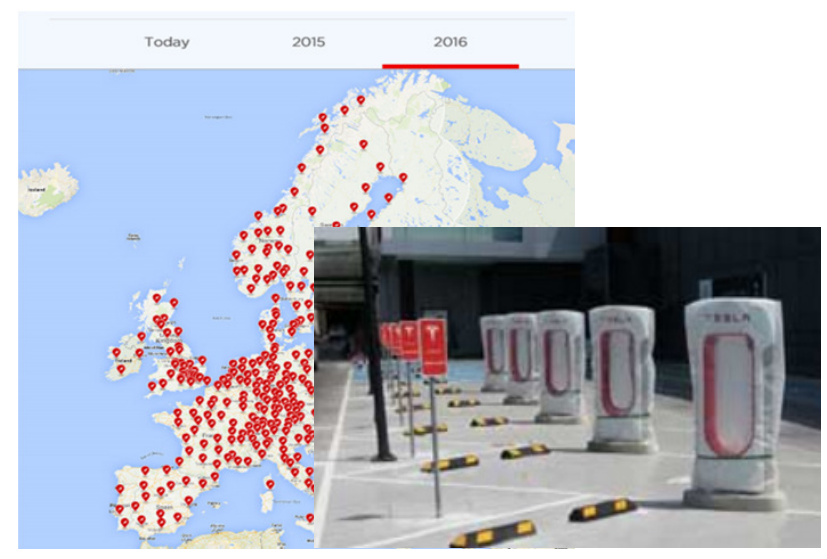

Figura 4.18. Rede europeia de postos de supercarregamento da Tesla (esq.) e à direita o recente posto em Murcia (Espanha)

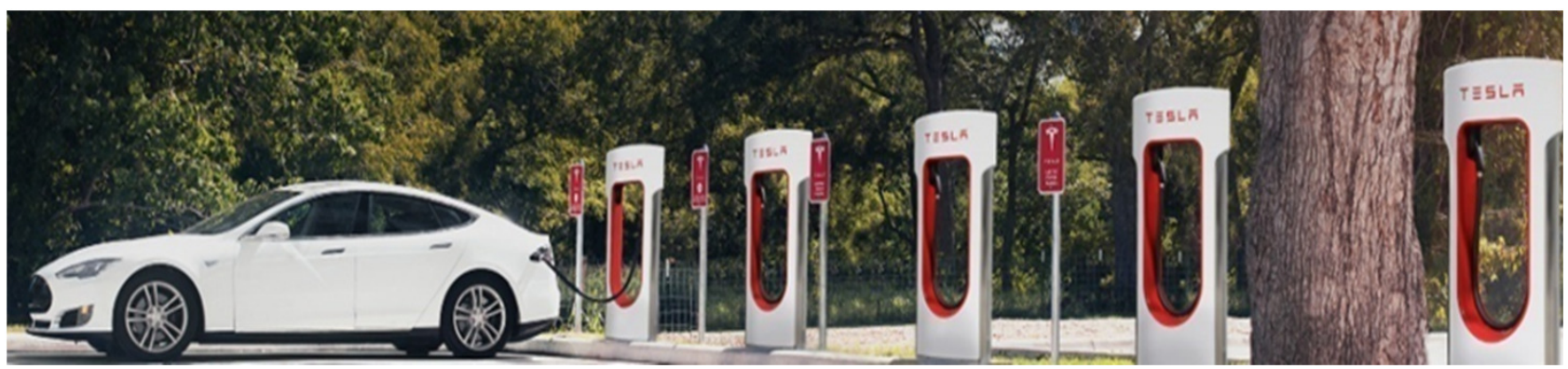

Figura 4.17. Supercarregadores da Tesla 
- Solução para resolver o problema dos carregamentos em Portugal

A penetração de VE em Portugal tem sido reduzida, mas com a chegada da 2a geração, a partir do próximo ano com baterias de $60 \mathrm{kWh}$, conjugado com a também prevista redução do seu preço, é realisticamente previsível um aumento acelerado de vendas.

Na hora da decisão de o comprar, o consumidor terá que primeiro equacionar onde irá carregar o seu carro. Com a rede atual da MOBI.E, não será um problema fácil de resolução, por maioritariamente ser constituída por pontos de carga lenta.
A instalação de uma rede de carregadores rápidos em número equivalente, pelo menos aos dos postos de abastecimento de combustíveis convencionais, seria a solução mais sensata, para as zonas urbanas que maioritariamente são constituídos por prédios multifamiliares.

O aproveitando das infraestruturas elétricas existentes, como por exemplo nos centros comerciais ou mesmo nos postos de abastecimento atuais, baixaria o investimento, que depois se poderia traduzir num menor pagamento no carregamento. Ao longo das vias rodoviárias principais, a instalação de postos de carregamento rápido, nas áreas de serviço existente ou perto dos nós de acesso, seria o ideal para percursos mais longos.

Notas soltas:

Grau de proteção contra os impactos mecânicos (Código IK)

EN 62262 - Graus de segurança assegurada pelos invólucros para equipamentos elétricos contra impactos mecânicos externos (código IK).

A designação do invólucro de um aparelho em relação ao grau de proteção contra os impactos mecânicos deverá ser realizada da seguinte forma: IK XX

Codificação do grau de proteção contra os impactos mecânicos (código IK)

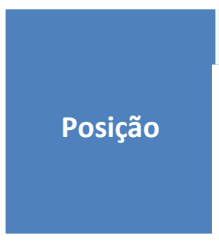

\begin{tabular}{c}
1 \\
\hline Letras do código \\
(Proteção mecânica \\
internacional)
\end{tabular}

2
Grupo de
números
característico

IK

De 00 a 10
Significado dos grupos de números característicos do grau de proteção contra os impactos mecânicos (código IK)

\begin{tabular}{|c|c|}
\hline Código IK & Energia de impacto (Joule) \\
\hline 00 & Não protegido \\
\hline 01 & 0.14 \\
\hline 02 & 0.20 \\
\hline 03 & 0.35 \\
\hline 04 & 0.50 \\
\hline 05 & 0.70 \\
\hline 06 & 1 \\
\hline 07 & 2 \\
\hline 08 & 5 \\
\hline 09 & 10 \\
\hline 10 & 20 \\
\hline Quando for necessário um valor de energia de impacto superior, é \\
\hline recomendado a utilização do valor de 50 Joule. \\
\hline
\end{tabular}

